\title{
Entrepreneurial Career of Students in Agriculture: An Analysis
}

\author{
Diego A. Waguey* \\ Social Science Research and Development Center, Don Mariano Marcos Memorial State University, South La Union Campus, Agoo, \\ La Union, Philippines \\ *Corresponding author: diegzwaguey@yahoo.com
}

Received December 30, 2013; Revised January 13, 2014; Accepted January 20, 2014

\begin{abstract}
The study analyzed the entrepreneurial career of students in agriculture. The output of the research is deemed important for planning actions or interventions designed to improve or enhance the entrepreneurial potentials of agriculture students that will empower them to create opportunities for agricultural and industrial development. The study made use of 175 students taking up agriculture who were randomly selected as respondents. The study used achievement motivation, work habits and attitudes as indicators of entrepreneurial career index of the students. Results indicated that $52 \%$ of the respondents have moderately high to high potential ability to engage, sustain, and succeed as entrepreneurs. Relative to achievement motivation, the respondents have high potential ability to: 1) forego small conveniences or discomfort at present in favor of a much bigger and more satisfying returns in the future; 2) focus their energies on the task to be able to accomplish things; and 3) associate with people who work hard and who are knowledgeable about the things they are interested in. On the other hand, the respondents tendnot to likely use their time productively. In terms of work habits and attitudes, the respondents have the following potentials: 1) ability to take upon themselves responsibilities and tasks rather than depending on others, 2) ability not to allow conditions to determine their attitudes towards work, and 3) ability to make responsive and timely decisions. However, they have the tendency not to believe in their abilities or capacities in comparison with others. Findings further showed that students belonging to disunited families and students with entrepreneurial experiences have better entrepreneurial career index than those belonging to intact families. Students who finished and those who are still taking the subject on entrepreneurship and students who have experiences on entrepreneurship have better work habits and attitudes. Results are significant inputs to entrepreneurship education particularly in the field of agriculture as to which characteristics or traits should be developed or be further enhanced among students and as to who should be encouraged and be advised to engage in entrepreneurship. While students possess qualities at varying degrees, it is an important strategy to make them aware of their strengths and weaknesses and to guide them build traits and characteristics necessary for entrepreneurship.
\end{abstract}

Keywords: entrepreneur, career, agriculture

Cite This Article: Diego A. Waguey, "Entrepreneurial Career of Students in Agriculture: An Analysis.” American Journal of Educational Research, vol. 2, no. 1 (2014): 35-43. doi: 10.12691/education-2-1-7.

\section{Introduction}

Most economists agree that entrepreneurship is essential to the vitality of any economy, developed or developing [1]. Entrepreneurship has widely been considered as a solution to economic and unemployment problems. It creates employment, improves the quality of life, contributes to more equitable distribution of income, utilizes and mobilizes resources for greater national productivity and brings social benefits through the government [2]. With these contributions of entrepreneurship, we can conclude that the more a society engages in entrepreneurial undertakings, the more it is likely to develop economically and socially.

In recognition to the role of entrepreneurs to economic growth and development, many curricular programs in the tertiary level have included entrepreneurship as a subject to develop the entrepreneurial skills of students. Inspite of this effort, the Philippines still lacks indigenous entrepreneurs-individuals who are moderate risk takers, daring and innovative, assertive and highly motivated [3].

Agriculture is one of the economic sectors in the Philippines where there is a wide range of business or enterprise opportunities. The transformation of these opportunities to economic development, however, depends on many factors. The most crucial factor is the entrepreneur, the manager and organizer of the other factors. Recognizing the crucial role of entrepreneurs in agribusiness development, entrepreneurship is included as a subject in many agriculture courses. The inclusion of entrepreneurship as a subject is expected to enhance, develop and hone the knowledge, skills, attitudes and values of the students. Entrepreneurship is a career that demands the best decisions and actions to be able to start and sustain the enterprise/business. Entrepreneurship is a 
self-dictating activity. As such, it requires positive and desirable behaviors or traits to able to make sound decisions and actions.

Given this premise, it is imperative to determine the likely behaviors of students enrolled in agriculture which are reflective of their entrepreneurial career. The determination of the likely behaviors of students will serve as basis in deciding what behaviors need improvement as the quote goes "build upon strengths and the weaknesses will gradually take care of themselves" [4]. Further, the identification of factors related or linked to the likely behaviors of the students will be a significant input in the development of entrepreneurial career framework of students. The framework can serve as a guide in enhancing and developing the potentials of students particularly those taking courses in agriculture.

\subsection{Significance of the Study}

The study is deemed significant in providing information to the faculty and administrators of institutions offering agriculture. Findings could serve as basis in improving and enriching the agriculture curriculum. The output of the research will serve as framework in deciding and planning the attributes or traits to be emphasized and integrated not only in the subject on entrepreneurship but in the other subjects as well. Likewise, the information generated by this research will also serve as basis in providing advice and career guidance to students in agriculture. In effect, this will broaden the employment and economic opportunities of agriculture graduates.

\subsection{Objectives of the Study}

The study generally aimed to analyze the entrepreneurial career of students enrolledin agriculture courses. Specifically it aimed to: 1) determine the achievement motivation of the students using the following indicators: a) hard work, b) future orientation, c) aspiration, d) task/goal orientation, e) upward mobility, f) persistence, g) preference for experts as work partners, and h) use of time productively; 2) determine the work habits and attitudes of the students through the following indicators: a) source of motivation, b) thoughts, c) time utility, d) work attitudes, e) concern for feedback or result on performance, f) self-confidence, e) leadership potential and g) decision making; 4) determine the entrepreneurial career index of the students in agriculture; 5) identify factors associated or related to achievement motivation, work habits and attitudes, and entrepreneurial career index; and 5) use the result of the study in coming up with recommendations designed to improve the entrepreneurial career of students taking up agriculture.

\subsection{Conceptual Framework}

The entrepreneurial career of students can be defined by their achievement motivation and, work habits and attitudes. The achievement motivation reflects the potential ability or capacity of a student to exert his/her best effort to attain the goals he/she sets. On the other hand, work habits and attitudes refer to the manner by which a student will likely respond or react in accomplishing and sustaining his/her efforts to attain the goals. The most commonly used traits to survey potential entrepreneurs are locus of control and need for achievement. Researchers are more unanimous of the predicting power of values, attitudes and motivation as factors affecting entrepreneurship [2]. However, no single indicator can cover all the dimensions of a concept, and a number of indicators have to be selected [5].

Achievement motivation is the basis for a good life. People who are oriented towards achievement, in general, enjoy life and feel in control. They prefer to work on a problem rather than leaving the outcome to chance [6]. They have high aspiration level and they prefer experts as work partners. They also value upward mobility and time [3]. This is so because they possess the following characteristics or traits such as hard working, futureoriented, task-oriented, and persistent.

Individuals with high achievement motivation are more likely to be attracted to occupations that offer high degrees of control over outcomes, personal responsibility, feedback on performance, and moderate degree of risk [10]. Successful entrepreneurs are not thwarted by their defeat. They look at defeat as an opportunity for success. They are determined to make all of their endeavors succeed, so they try and try again until they do. They do not believe that something cannot be done [7]. Available literatures pointed that achievement-oriented individuals get ahead of life. Entrepreneurially inclined students have higher risk taking propensity, internal locus of control, higher need for achievement and higher innovativeness [11]. A number of previous studies pointed that achievement motive is positively related to growth ambitions [12].

Meanwhile, the manners by which tasks are accomplished depend on the attitudes and habits of the individuals doing the tasks. Empirical evidences tend to indicate that there are far more people who can start a business than there are who can run a business and prosper over the long haul. MBA (Masters in Business Administration) students and graduates who are interested in entrepreneurship have positive values and attitudes towards entrepreneurship and in their own opinion have the capability for entrepreneurship [2].

The question on whether entrepreneurs are made or born is not a debatable issue. There are empirical evidences proving and showing that entrepreneurs are made. The entrepreneurial career of a person as measured by his achievement motivation and attitude is related or associated to family background and experiences in life. Based on literatures, the entrepreneurial career of a person maybe associated to his experiences in life. Students who finished the course on entrepreneurship are expected to possess better entrepreneurial career compared to those who haven't finished or taken the subject. Meanwhile students who come from broken or disunited families have better entrepreneurial career compared to students coming from a more united or intact families. There were findings supporting that a significant number of successful entrepreneurs come from families which have been unstable and had experienced crisis situations like death of one or both parents. Moreover, entrepreneurs generally come from small families and if they come from large families, they are usually the oldest and sometimes the middle child. Parenting style has likewise been identified to be associated with entrepreneurial career. Results of 
studies revealed that entrepreneurs come from parents who are more permissive or democratic and not from parents who are authoritarian [3]. Personality traits and parenting may be related with entrepreneurial competence and entrepreneurial interest [8].

Meanwhile, family income is hypothesized to be associated with entrepreneurial career. Families with lower income are expected to put pressure to their children to help the family generate income; thus, developing the traits and habits favorable to entrepreneurial career development. The nature of the parents' occupation has also been identified to be associated with entrepreneurial career of their children. The exposures of children to parents who are in business or in related occupations seem to help develop their children's entrepreneurship skills [3].

Meanwhile, students who experience business or trading and have positive view about business are expected to possess better entrepreneurial career. Relative profit tends to be high when an entrepreneur has more education and experience in the line of business [9]. Likewise, work experience is one of the factors affecting entrepreneurship [2].

\subsection{Research Hypotheses}

Based from the conceptual framework of the study, the following were hypothesized: 1) the level of achievement motivation of the students is related or associated to their profile or background; 2) the work habits and attitudes of the students are also associated to their profile or background; and 3) the sum of the achievement motivation and the work habits and attitudes (entrepreneurial career index) of the students are related or associated to their profile.

\section{Methodology}

\subsection{Research Design}

The study made use of the descriptive survey type of research since the aimis to describe and analyze the entrepreneurial career of the students as a basis of determining future program interventions or actions.

\subsection{Respondents}

The respondents of the study consisted of one hundred seventy five students taking up agriculture at the Don Mariano Marcos Memorial State University, Philippines. The respondents were enrolled during the first semester of school year 2012-2013. The number of samples was determined or computed using the Sloven's formula. The stratified sampling technique was used to ensure that the four-year levels are represented. Selection of samples per year level was done through simple random sampling. The samples per year level were as follows: first year $=56$, second year $=76$, third year $=23$, and fourth year $=20$.

Forty seven percent are males and fifty three are females. The average number of siblings of the respondents is five. Majority of the fathers of the respondents are farmers, while their mothers are housekeepers. Majority of the respondents belong to intact family structure with an annual income below 10,000 pesos. The respondents' parents are generally authoritative in treating or in dealing with their children. Sixty two percent of the respondents have entrepreneurial experience.

\subsection{Research Instrument}

The data were collected using questionnaires which were answered by the students. The questionnaire was composed of three parts. Part 1 consisted of the profile or background of the students; part II consisted of items that measured the students' achievement motivation; and part III consisted of items that measured their work habits and attitudes. The achievement motivation and work habits were adapted from appraisal instrument used by SERDEF (Small Enterprise Research and Development Foundation). Point equivalents or scores per item were likewise adopted. However, the score categories or classifications set by SERDEF were slightly modified by expanding the number of categories. The instruments were personally administered by the researcher to allow students to clarify questions or items that are not clear. There search instrument was administered from August to September 2012.

\subsection{Data Analysis}

The different indicators of achievement motivation were categorized as follows based on the score of the students in each indicator: 0 and below = low, 1-2 = average or moderate, and 3-4 = high. The highest possible score per achievement motivation indicator is +4 and the lowest is -4 as there are two questions for each indicator. The scores of the students on the different achievement motivation indicators were summed or aggregated algebraically and were categorized as follows: below $8=$ low, 8-19 = average or moderate, and 20 and above $=$ high. For work habits and attitude indicators, the descriptive equivalents of the scores were as follows: $0=$ low, 1 = moderate or average, and 2 = high; and for decision-making, $0=$ low and $1=$ high. The overall score of the students on work habits and attitudes had the following categories: 7 \& below = Low, 8-11 = Moderate or Average, and 12 and above $=$ high.

The overall score of each student under motivation achievement and work habits and attitudes were indexed by dividing the student's actual score by the highest possible score in each indicator. This was done to standardize the unit of the indicators which allowed the summation of the two indicators. The achievement motivation index and the work habits index were summed and divided by 2 to reflect or represent the entrepreneurial career index of the student. The entrepreneurial career index was categorized as follows: 0.34 and below = low, 0.35-0.49 = moderately low, 0.50-0.64 = moderately high and 0.65 and above $=$ high. The arbitrary index classifications or groupings were based from the indicators' classification. The entrepreneurial career index ranged from $0-1$.

The data were tabulated and analyzed using the SPSS program 19.0 version. The nominal and ordinal data were numerically coded to facilitate statistical analysis. Frequency counts were used to summarize and describe the characteristics of the students. Correlation analysis was used to test the hypotheses using 5\% level of significance. 


\section{Results and Discussion}

This part presents the discussion of the results to answer the objectives of the study. Specifically, it presents the students' a) level of achievement motivation and its indicators, b) work habits and its indicators, c) entrepreneurial career index, and d) the profile variables that were hypothesized to be associated or related with achievement motivation, work habits, and entrepreneurial career index.

\subsection{Achievement Motivation of the Students}

Entrepreneurship as a career is a highly competitive and challenging undertaking and therefore demands a higher level of achievement motivation-a higher-level of willingness of prospective entrepreneurs to exert their best effort in order to attain the goals they set. Achievement motivation is significantly correlated with both choice of an entrepreneurial career and entrepreneurial performance [10].

Table 1. Distribution of the Respondents According to the Category of their Achievement Motivation

\begin{tabular}{|c|c|c|c|c|c|c|c|c|}
\hline \multirow{3}{*}{$\begin{array}{l}\text { Achievement Motivation } \\
\text { Indicators }\end{array}$} & \multicolumn{6}{|c|}{ Score Group/Category } & \multirow{2}{*}{\multicolumn{2}{|c|}{ Total }} \\
\hline & \multicolumn{2}{|l|}{ Low } & \multicolumn{2}{|c|}{ Moderate/Average } & \multicolumn{2}{|l|}{ High } & & \\
\hline & $\mathrm{N}$ & $\%$ & $\mathrm{~N}$ & $\%$ & $\mathrm{~N}$ & $\%$ & $\mathrm{~N}$ & $\%$ \\
\hline Hard work & 28 & 16.00 & 107 & 61.14 & 40 & 22.86 & 175 & 100 \\
\hline Upward Mobility & 45 & 25.71 & 73 & 41.72 & 57 & 32.57 & 175 & 100 \\
\hline Persistence & 27 & 15.43 & 116 & 66.29 & 32 & 18.28 & 175 & 100 \\
\hline Future Orientation & 30 & 17.14 & 47 & 26.86 & 98 & 56.00 & 175 & 100 \\
\hline Aspiration & 66 & 37.71 & 83 & 47.43 & 26 & 14.86 & 175 & 100 \\
\hline Goal Orientation & 5 & 2.86 & 35 & 20.00 & 135 & 77.14 & 175 & 100 \\
\hline Preference for Experts as Work Partners & 6 & 3.43 & 45 & 25.71 & 124 & 70.86 & 175 & 100 \\
\hline Use of Time & 140 & 80.00 & 34 & 19.43 & 1 & 0.57 & 175 & 100 \\
\hline Achievement Motivation & 25 & 14.29 & 133 & 76.00 & 17 & 9.71 & 175 & 100 \\
\hline
\end{tabular}

Findings as presented in Table 1, show that majority of the students scored high on three indicators of achievement motivation, future orientation, goal orientation, and preference for experts as work partners. The table specifically shows that $56 \%$ or roughly 6 for every 10 students have high future orientations which means that majority of the students have the potential ability or tendency to forego small conveniences or discomforts at present in favor of a much bigger and a more satisfying return in the future. Likewise, majority or roughly 8 for every 10 students have high task/goal orientation indicating their potential ability to focus their energies on the task to be able to accomplish things. Lastly, majority or 7 for every 10 students have high preference for experts as work partners which reflects their potential ability to associate with people who work hard and who are knowledgeable about the things they are interested in. The great entrepreneurs always know when they cannot do something and they are wise to find others who can [4].

Meanwhile, majority of the students are categorized as moderate or average on hard work, persistence, and aspirations. The moderate likely behavior of students on hard work reflects the tendency of the students not to fully exert their best in everything they do. Likewise, the average or moderate persistence reflects the tendency of the students to shift momentum when faced with hardships and difficulties. The moderate level of aspirations of the students suggests that they have the tendency not to fully demand or rely upon themselves when given work or a task. The tendency of the students to limit their efforts at some critical points when given a work or task will proportionately affect their efficiency, productivity, and sustainability of their activity. If entrepreneurs are ambivalent or mildly enthused about their product or service, that's not going to sustain them through the highs and lows that will inevitably occur [13]. Findings suggest then that the students still need to improve on these areas considering that entrepreneurship is a challenging and highly competitive undertaking that demands superlative efforts in doing things in order to achieve excellence and quality outputs.

Meanwhile, it is very alarming and disturbing that $80 \%$ or 8 for every 10 students are low on the value of time or making every moment count. Finding indicates that the students will likely use a significant proportion of their time to non-productive activities. The inability of the students to use time productively will surely affect their potential productivity. In business, every moment should be regarded or considered as an opportunity to be productive.

Overall, $76 \%$ of the respondents belong to moderate or average achievement motivation. It is important to note that the eight indicators of achievement motivation are interdependent. Thus, each indicator has a significant effect on the overall achievement motivation of the students. The inability of the respondents to productively use their time and their relatively low aspirations are significant minus factors to their overall achievement motivation which implies that if a student will score extremely low in a certain indicator, it will certainly pull down significantly his/her overall achievement motivation. Findings suggest the need to reorient and develop the students on the value of time where they should strive to make every moment productive and to demand more from themselves when given a task or activity.

\subsection{Work Habits and Attitudes of the Respondents}

Entrepreneurship is a career that requires or demands positive response or reaction in accomplishing a task or goal and a high level of willingness in sustaining efforts to attain such goal. Results indicate that majority of the students scored high on the following indicators of work habits and attitudes: self-motivation, work attitude, feedback, and decision-making. The high score on selfmotivation indicates that majority of the students will 
likely take upon themselves responsibilities or tasks rather than depending upon others. Likewise, majority of the students scored high on work attitude indicating that they will not likely allow conditions to determine their attitudes towards work. The students also scored high on decisionmaking which suggests that the students will likely make responsive and timely decisions. The decisive tendency of the respondents is a remarkable positive attribute considering that in business, several decisions are to be made each day. Majority of the students have the ability or concern to use feedbacks to further improve their performance and to treat or consider it as a learning experience. Result suggests that majority of the students have the tendency to rely on facts whenever they are available and to adjust their estimates of risks accordingly.

Table 2. Distribution of the Respondents According to their Work Habits and Attitudes

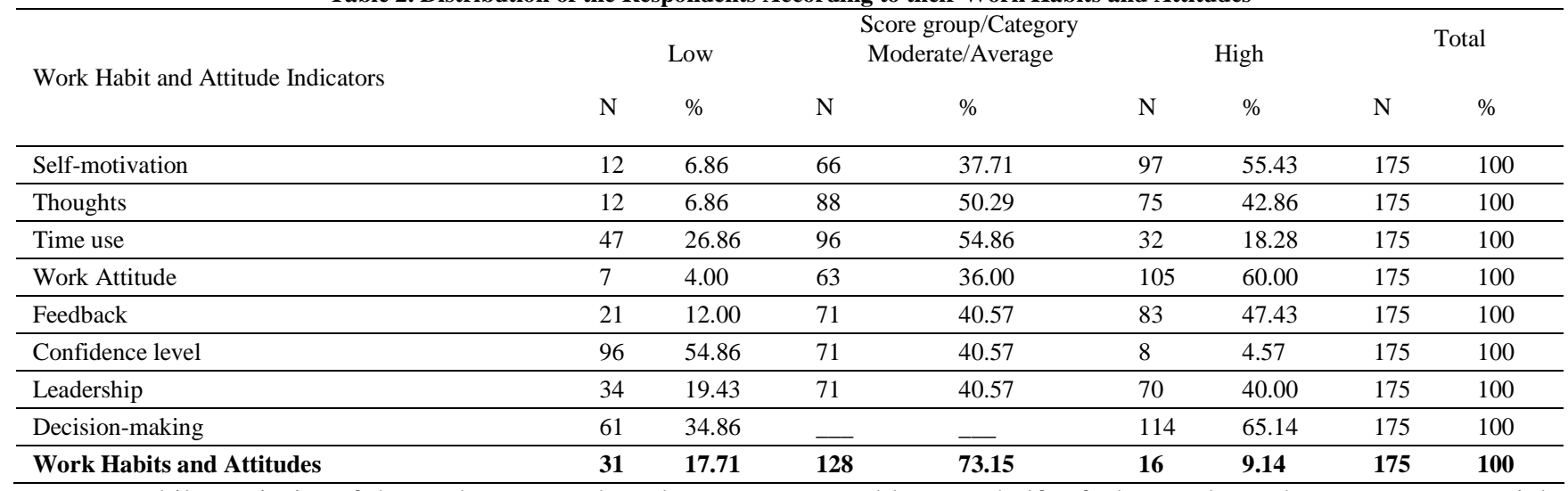

Meanwhile, majority of the students scored moderate or average on thoughts and time use. Findings indicate that majority of the students have the tendency not to seriously think of productive or innovative endeavors or activities and not to consistently utilize their time for productive and innovative activities. Entrepreneurship is a highly demanding and competitive career or profession that requires higher and sustainable level or order of creativity, innovativeness, and time consciousness. Many experts believe that it is the innovativeness of entrepreneurs which largely and continuously revolutionizes everyday living.

Significantly, majority of the respondents scored low on self-confidence which suggests that majority of the students tend to view their abilities or capacities to be inferior in comparison with others. Advocates of entrepreneurship emphasized that, to be a successful entrepreneur, one must have the tendency to overestimate his/her chance of success, to set higher levels of expectations, and to believe in his ability to influence outcome more than other people do. Lack of confidence restricts individuals in doing their best [3].

Overall, the students scored average or moderate on work habits which suggests that the students sometimes have the tendency not to willingly and consistently react positively to exert efforts in order to sustainably accomplish a task to be able to reach his/her goal.

\subsection{Entrepreneurial Career Index of the Respondents}

Empirical evidences point that success of an entrepreneur is influenced by a) his/her willingnessto exert his/her efforts to attain the goal he/she sets and on the manner by which he/she will likely respond or react in accomplishing a task or goal and b) on the degree of his willingness to sustain such efforts to attain the goal he/she sets.

The entrepreneurial career index reflects the combined traits of the students (achievement motivation and, work habits and attitudes) which are considered key indicators of entrepreneurs' success. Table 3 shows that $52 \%$ or

roughly one half of the students have entrepreneurial career index ranging from moderately high to high. Result indicates that roughly one half of the students in agriculture have the potential ability to fully exert their effort and react positively or favorably sustain such effort in accomplishing a task. Result may imply that half of the respondents generally have the potential traits to be successful entrepreneurs.

Table 3. Distribution of the Respondents According to their Entrepreneurial Career Index

\begin{tabular}{lcc}
\hline \multicolumn{1}{c}{ Entrepreneurial Career Index Category } & Frequency & Percent \\
\hline Low (Below 0.35) & 19 & 10.86 \\
\hline Moderately low (0.35-0.49) & 65 & 37.14 \\
\hline Moderately high (0.50-0.64) & 73 & 41.71 \\
\hline High (0.65 and above) & 18 & 10.29 \\
\hline Total & 175 & 100.00 \\
\hline \multicolumn{1}{c}{ Meanwhile $48 \%$ of the respondents have an }
\end{tabular}

entrepreneurial career index ranging from low to moderately low which suggest that almost one half of the respondents do not possess or do not consistently possess the desirable entrepreneurial qualities or attributes that entrepreneurship demands. It means that almost one half of the respondents either lacked the required level of achievement motivation or work habits or both which entrepreneurs should possess. Result implies that a significant number of the respondents are not yet ready or not prepared to enter the world of entrepreneurship considering that the job or work of entrepreneurs requires a lot of energy and self-discipline. Result suggests that the mentors/faculty members teaching agriculture must exert more efforts to further improve or enhance the entrepreneurial traits or qualities of the students particularly the specific indicators where the students are relatively weak.

\subsection{Relationship Between the Respondents' Profile and Their Achievement Motivation}


Whether entrepreneurial traits are innate or acquirable, it is certain that the ability of a person to willingly exert efforts to do a task or work is influenced by the environment or culture upon which he/she lives or is exposed to.

Table 4. Matrix Showing the Correlation Coefficients between the Students' Profile and their Achievement Motivation Achievement Motivation Indicators

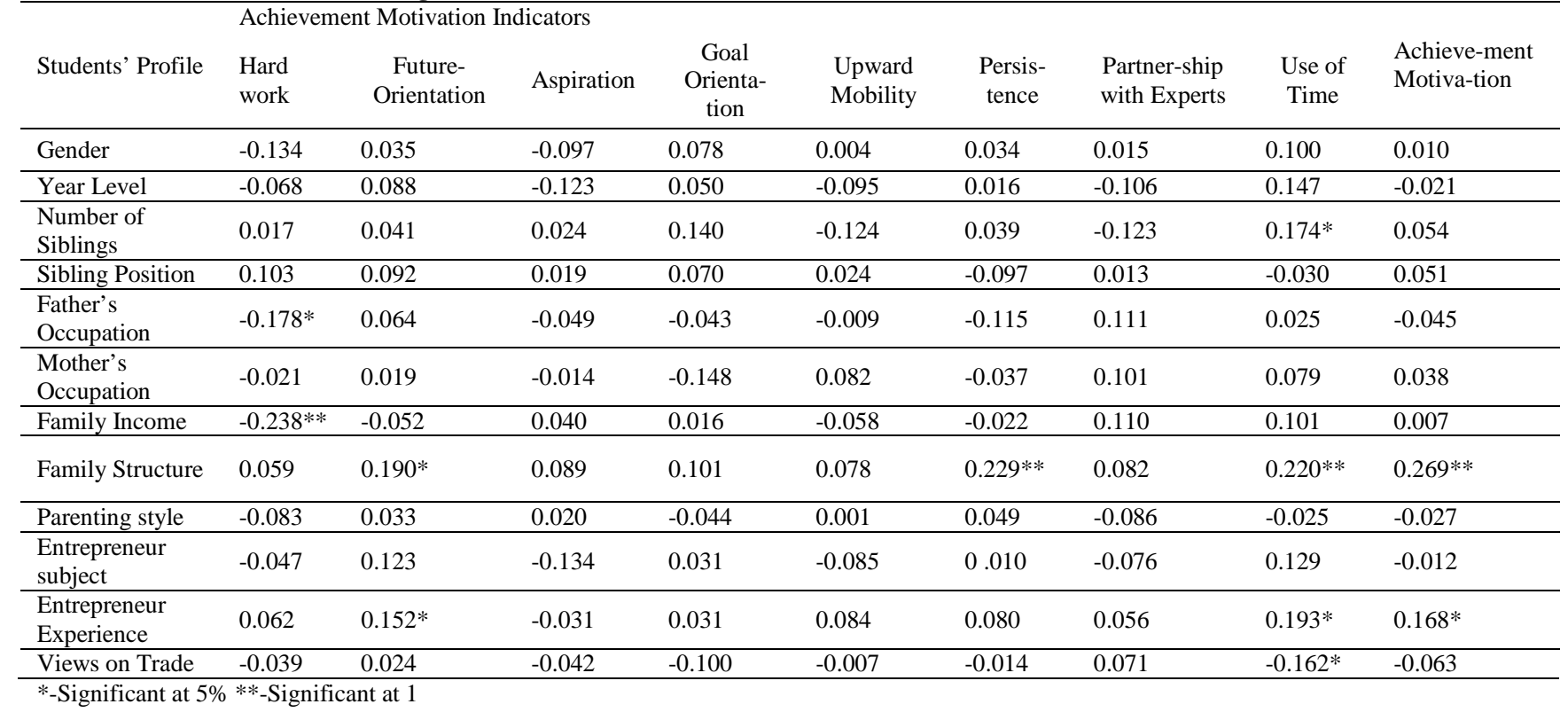

Results show that of the 12 profile variables that were hypothesized to be correlated with achievement motivation, only family structure and entrepreneurial experience were significantly related or associated with achievement motivation. Findings indicate that students who belong to disunited families (separated parents, death of parents, and single parent) have significantly higher or better achievement motivation than those who belong to intact families. Result suggests that the students who belong to disunited families have greater potential to exert more efforts in order to achieve their entrepreneurial goals than those students who belong to intact families. Result implies that students who belong to disunited families have a higher chance or likelihood to be successful entrepreneurs, considering that achievement motivation has been identified most frequently with individuals who are successful entrepreneurs. Finding corroborates with the observation that a significant number of successful entrepreneurs come from families which have been unstable and had experienced crisis situations like, death of one or both parents [3]. The significant relationship between family structure and achievement motivation may be attributed to the fact that students who come from disunited families tend to have higher or better future orientations, persistence, and that they value time for productive activities. This means that students who come from disunited families have a better potential ability to forgo small conveniences and to accept discomfort at present in favor of a much bigger and more satisfying returns in the future. They also have a better potential to do tasks even in the face of hardships and difficulties and to use their time more productively. These traits of students belonging to disunited families could be a result of their early life experiences to feed themselves, to seek means of livelihood and to make decisions on their own. Moreover, the entrepreneurial experience of the students is likewise related with achievement motivation whereby students who have entrepreneurial experience have better or higher achievement motivation compared to those who have no entrepreneurial experience. The reason for the higher achievement motivation of the students with entrepreneurial experience can be attributed to their high future orientation and better time utility as indicated by a significant correlation between entrepreneurial experience and future orientation and time utility. Finding is consistent with the claim that work experience is one of the factors affecting entrepreneurship [2]. Result implies that students who have entrepreneurial experience have a greater likelihood to be more successful entrepreneurs compared to those who have no entrepreneurial experience. Finding suggests that students or individuals who are planning to put up business or enterprise are encouraged to immerse themselves to entrepreneurial activities in order to enhance their achievement motivation, thus, developing their entrepreneurial skills and abilities.

The other independent variables such as year level, gender, number of siblings, sibling position, parents', occupation, family income, parenting style, finished course or subject on entrepreneurship and views on trade are not significantly related with the students' overall achievement motivation. However, it could be noted from the table that fathers' occupation is significantly related with hard work whereby students whose parents' occupation belong to lower level skills scored higher or better in their achievement motivation compared to students whose parents' occupation belong to higher level skills or professions. Likewise, it was noted that the lower the family income a student belongs, the higher is his/her score on hard work. This means students belonging to the lower income group have tendency to exert more efforts to do their best in everything they do and to value more the importance of hard work.

The number of siblings is likewise significantly related with time utility which indicates that the more the number of siblings, the better is the score on time utility. Result further indicates that students with more siblings have a higher tendency to use their time more productively. Meanwhile, there is a significant correlation between 
students' views on trade and time utility. Students who view trade or humble ventures negatively scored higher on time utility than those students who view trade positively. This means that students with negative views on trade have a better potential ability to use their time productively. This finding contradicts the results of previous studies that a culture that desires to develop more entrepreneurs must reward people who try to earn money from humble ventures [2]. It must view peddlers, vendors, and other traders not as object of pity but rather with admiration and praise.

\subsection{Relationship Between the Students Profile and Work Habits and Attitudes}

It was hypothesized that work habits and attitudes are related to the profile of the students on the premise that work habits and attitudes are products of one's experiences.

Table 5. Matrix Showing the Correlation Coefficients between the Profile of the Students and their Work Habits and Attitudes

\begin{tabular}{|c|c|c|c|c|c|c|c|c|c|}
\hline \multirow[b]{2}{*}{ Students' Profile } & \multirow[b]{2}{*}{$\begin{array}{l}\text { Motiva-tion } \\
\text { Source }\end{array}$} & \multicolumn{7}{|c|}{ Work Habit and Attitude Indicators } & \multirow[b]{2}{*}{$\begin{array}{l}\text { Work Habits } \\
\text { \& Atti-tudes }\end{array}$} \\
\hline & & Thoughts & $\begin{array}{l}\text { Time } \\
\text { use }\end{array}$ & $\begin{array}{c}\text { Work } \\
\text { Atti-tudes }\end{array}$ & $\begin{array}{l}\text { Concern for } \\
\text { feedbacks }\end{array}$ & $\begin{array}{c}\text { Confi- } \\
\text { dence level }\end{array}$ & $\begin{array}{l}\text { Leader- } \\
\text { ship }\end{array}$ & $\begin{array}{l}\text { Decision- } \\
\text { making }\end{array}$ & \\
\hline Gender & 0.089 & 0.180 & 0.138 & 0.082 & 0.018 & -0.103 & 0.106 & $-0.158 *$ & -0.016 \\
\hline Year Level & 0.189 & 0.064 & -0.022 & 0.106 & -0.092 & 0.067 & 0.021 & 0.106 & 0.137 \\
\hline $\begin{array}{l}\text { Number of } \\
\text { Siblings }\end{array}$ & 0.147 & -0.027 & 0.058 & -0.117 & -0.091 & 0.120 & -0.077 & -0.015 & -0.004 \\
\hline Sibling Position & 0.038 & 0.060 & -0.019 & 0.063 & 0.041 & -0.050 & -0.109 & 0.026 & 0.091 \\
\hline $\begin{array}{l}\text { Father's } \\
\text { Occupation }\end{array}$ & 0.011 & 0.017 & 0.074 & 0.050 & -0.069 & 0.034 & 0.106 & 0.094 & -0.011 \\
\hline $\begin{array}{l}\text { Mother's } \\
\text { Occupation }\end{array}$ & 0.138 & 0.113 & 0.064 & 0.074 & 0.025 & 0.144 & 0.042 & 0.035 & 0.098 \\
\hline Family Income & $0.211 * *$ & 0.024 & -0.083 & -0.117 & 0.011 & 0.011 & -0.085 & 0.121 & 0.017 \\
\hline Family Structure & 0.031 & 0.080 & 0.131 & 0.038 & 0.118 & 0.073 & -0.010 & -0.024 & 0.093 \\
\hline Parenting style & 0.116 & -0.043 & -0.043 & 0.113 & 0.132 & -0.129 & -0.028 & 0.023 & 0.039 \\
\hline $\begin{array}{l}\text { Entrepreneur } \\
\text { subject }\end{array}$ & 0.213 & 0.046 & -0.024 & $0.151 *$ & 0.082 & 0.045 & 0.058 & 0.120 & $0.167 *$ \\
\hline $\begin{array}{l}\text { Entrepreneur } \\
\text { Experience }\end{array}$ & -0.028 & 0.060 & 0.057 & 0.175* & -0.064 & -0.046 & 0.092 & 0.065 & $0.176 *$ \\
\hline Views on Trade & 0.090 & 0.050 & -0.007 & 0.150* & 0.108 & $0.256 * *$ & 0.055 & -0.051 & 0.022 \\
\hline
\end{tabular}

*-Significant at $5 \%$ **-Significant at $1 \%$

Results show that of the twelve student profile variables that were correlated with the overall score of the students on work habits and attitudes, only entrepreneur subject and experience were found to be significantly related or associated with work habits. It could be noted that students who have finished and those still taking the subject on entrepreneurship scored better on work habits than those who have not yet enrolled the subject on entrepreneurship. Result implies that taking or finishing the subject on entrepreneurship can improve or enhance the manner by which the students positively respond or react in accomplishing a task or a goal. The common characteristics of successful entrepreneurs can be learned by practicing and by developing a winning attitude, especially if they set goals and apply by themselves, through strategic planning, to reach those goals in incremental and measurable stages [14]. Likewise, students who have had experience on entrepreneurship tend to have better potential work habits compared to those with no entrepreneurial experience. The significant relationship of the two variables with work habits maybe attributed to the significant correlation of work habits and work attitudes, whereby students who have taken or still taking the subject and those who have experiences on entrepreneurial activities have higher tendency not to allow conditions to determine their attitudes towards work.

Meanwhile, students' view on trade were significantly related with their work attitudes and self-confidence level although it was not significantly related with their overall work habits. The significant correlation between students' view on trade and work attitudes and confidence level indicate that students who view trade positively have better work attitudes and have higher self-confidence. This means that students who appreciate trade or humble ventures have better ability or tendency not to allow conditions to determine their work attitudes and to believe in their abilities or capacities in comparison with others.

Family income is also related significantly with the source of motivation which indicates that students belonging to the higher income level will more likely take upon themselves responsibilities or tasks rather than depending on others.

\subsection{Relationship Between the Students' Profile and Their Entrepreneurial Career}

The combined potential ability of the students to willingly exert effort and the ability to sustain such effort is hypothesized to be related their profile.

Statistical analysis reveals that family structure and entrepreneurial experience of the students are significantly related to their entrepreneurial career index. Students who come from disunited families tend to have significantly higher or better entrepreneurial career index. This significant relationship can be attributed to the fact that students who come from disunited families tend to have higher or better chance to attain the goals they set (achievement motivation) due their better ability to forgo small conveniences or discomfort at present in favor of a much bigger and more satisfying returns in the future. They likewise possess better potential ability to do tasks even in the face of hardships and difficulties.

Moreover, entrepreneurial experience is also related significantly with the entrepreneurial career index of the students. Students who have experience on entrepreneurship have better entrepreneurial career index. The significant relationship between entrepreneurial experience and entrepreneurial career index maybe 
attributed to the higher achievement motivation and better work habits and attitudes of those who have experience on entrepreneurship. It could also be noted that students who have experience on entrepreneurship have better future orientation, time utility and work attitudes compared to those students with no entrepreneurial experience.

Table 6. Correlation between Students' Profile and Entrepreneurial Career Index

\begin{tabular}{cc}
\hline Students' Profile & Entrepreneurial Career Index (r) \\
\hline Gender & 0.060 \\
\hline Year Level & -0.002 \\
\hline Number of Siblings & 0.033 \\
\hline Sibling Position & 0.085 \\
\hline Father's Occupation & -0.038 \\
\hline Mother's Occupation & 0.081 \\
\hline Family Income & 0.015 \\
\hline Family Structure & $0.236^{* *}$ \\
\hline Parenting Style & 0.003 \\
\hline Entrepreneur Subject & 0.084 \\
\hline Entrepreneurial Experience & $0.213^{* *}$ \\
\hline Views on Trade & -0.032 \\
\hline **-Significant at 1\% & \\
Meanwhile, it is reflected in Table 6 that gender, \\
number of siblings, sibling position, father's occupation, \\
mother's occupation, family income, parenting style, \\
status of entrepreneur subject, and views on trade of the \\
students are not significantly related with entrepreneurial \\
career.
\end{tabular}

\subsection{Conclusions}

Based from the results of the study, the following conclusions were derived: 1) Students in agriculture have generally moderate or average achievement motivation level. Particularly, the students have the tendency not to use their time productively. On the other hand, they have high potential tendency to: a) forgo small conveniences or discomfort at present in favor of a much bigger and more satisfying returns in the future; b) focus their energies on the task to be able to accomplish things; and c) associate with people who work hard and who are knowledgeable about the things they are interested in; 2) Students in agriculture are moderate or average in terms of their work habits and attitudes which indicate that there are indicators along work habits where they are relatively weak. Particularly, the students have the tendency not to believe in their abilities or capacities in comparison with others. Conversely, they will likely take upon themselves responsibilities or tasks rather than depending on others; will not allow conditions to determine their work attitudes; and will likely make a responsive or timely decision. Meanwhile, they have the tendency not to consistently respond or react favorably in accomplishing a task or work; 3) Students in agriculture do not generally possess the full package of traits demanded in the field of entrepreneurship as evidenced by their weaknesses in some of the indicators of both achievement motivation and on work habits and attitudes; 4) Generally, the students belonging to disunited families have higher achievement motivation or tendency to attain the goals they set than students who belong to united families; 5) Students with entrepreneurial experience have significantly better achievement motivation than those with no entrepreneurial experience; 6) The greater is the number of siblings a student belongs, the higher is his/her tendency to use time productively; and 7) Students who come from disunited families and students who have entrepreneurial experience have better potential entrepreneurial career.

\subsection{Recommendations}

Based from the findings of the study, the following actions are hereby recommended: 1) The achievement motivation level of the students taking up agriculture maybe improved specifically on the following areas: a) time utility for productive activities and a) higher aspirations. These traits maybe considered the priority traits or values that can be emphasized not only in entrepreneur subject but in every subject. Likewise, it is worth-emphasizing to remind students of their values on the following areas: a) the value and importance of hard work, b) the price of doing a task even in the face of hardships and difficulties (persistence), and c) the price of demanding more from themselves when given a work or task (aspiration). While, it is crucial to emphasize improving the weaknesses of the students in relation to entrepreneurship, efforts should be done to further improve and sustain their strengths. The work habits and attitudes of the students need further improvement in terms of their confidence level and use of time. These traits should be included in the core values or traits to be imparted among students in order to develop their career towards entrepreneurship. Side by side, there should be efforts to look into ensuring and sustaining students' abilities to rely upon themselves, to work unconditionally and to make responsive decisions; 2) Students who are products of broken or disunited families and those who have experiences on entrepreneurship should be guided carefully and be encouraged towards a career path directed towards entrepreneurship; 3) Students aiming to become entrepreneurs are encouraged to immerse themselves on entrepreneurship or economic activities even at a younger age in order to enhance and develop their achievement motivation and, work habits and attitudes which are inherently needed and demanded in the world of business or entrepreneurship; and 4) The analysis or appraisal of the entrepreneurial career of the students is recommended to other courses particularly courses that are designed to produce entrepreneurs. The identification of students' strengths and weaknesses will be a significant input in shaping and developing their entrepreneurial potentials and capabilities in facing the challenging and demanding environment of entrepreneurship.

\section{References}

[1] Holden, J., Principles of entrepreneurship, U.S. Department of State/Bureau of International Information Program, 2007.

[2] Maki K., Motivation for entrepreneurship among academics, www.sbaer.uca.edu/research/icsb/pdf, 1999.

[3] Small Enterprises Research and Development Foundation (SERDEF), Introduction to entrepreneurship. Diliman, Quezon City. 1989.

[4] Banerjee, J., Ten habits of highly successful entreprenuers, www. Jeetbanerjee.com.2012.

[5] Nachmias, C.andNachmias, D., Research methods in the social sciences, Great Brain: St Martin's Press, Inc.

[6] Romando, R., Achievement motivation. http://ezineartes/? Achievement-Notivation\&id=429438, 2007.

[7] Adams, J., TenQualities of a successful entrepreneur, http//under30ceo.com, 2010. 
[8] Rodermund, S., Pathways to successful entrepreneurship: Parenting, personality, early entrepreneurial competence, and interest.

[9] Jo, H and Lee, J, The relationship between an entrepreneur's background and performance in a new venture, Elsevier Ltd.

[10] Collins, C. J., Hanges, P. J., \& Locke, E. A., The relationship of achievement motivation to entrepreneurial behavior: A metaanalysis. Cornell University, IL School, http://digitalcommons.ilr.cornell.edu/articles/x, 2004.

[11] Gurol, Y and Atsan, N. "Entrepreneurial characteristics amongst University Students: Some insights for entrepreneurship education and training in Turkey”, Education + Training, vol. 48 Iss: 1, pp. 25-38., Emerald Group Publishing Limited, 2006.

[12] Hessels, J., Gelderon, M., \& Thurik, R., "Entrepreneuria aspirations, motivations and their drivers", Small Bus Econ, 31: 323-339.

[13] Key, S., Five Qualities of Successful Entrepreneurs, http.//www.entrepreneur.com.2013.

[14] Stephenson, J., 25 Common characteristics of successful Entrepreneurs, http//www.entrepreneur.com/article, 2013. 